\title{
5. The changing role of the Great Council of Chiefs
}

\section{Robert Norton}

The central dilemma in Fiji's political development has been the problem of how to devise constitutional government that can reconcile the indigenous Fijian conviction of entitlement to political pre-eminence with a just representation of the interests of other sections of the population, primarily the Indians. Both the army and the Great Council of Chiefs (GCC) have gained prominence during the last 20 years as institutions of indigenous Fijian power with capacities for the extra-constitutional management of crises arising after the electoral defeat of Fijian-dominated governments. Both have grappled with the dangerous force of Fijian nationalist sentiment, at times endorsing it and at times restraining it in the process of setting up new regimes. Army and political leaders have turned to the GCC for legitimation of their actions, and, in the decade following Rabuka's coups of 1987, the GCC came to be widely viewed as having an important national political role, notwithstanding the fact that its members are typically strongly ethnocentric.

A dramatic highlight of the aftermath of the army coup of December 2006, however, has been military commander Bainimarama's acrimonious conflict with the GCC. Whereas Rabuka had readily secured the chiefs' approval of his quest to re-instate a Fijian-dominated government, Bainimarama had, purportedly in the national interest, deposed such a government - indeed, one only recently returned to office by the vast majority of Fijian voters. The GCC refused to accept Bainimarama's claim to have taken authority from the President of Fiji, asked the army to return to barracks, and proposed that the President appoint a council to set up an interim regime. The commander's angry response was to direct the GCC not to meet again without his approval. Continuing resistance from the GCC provoked Bainimarama to declare he was dissolving its current membership in preparation for a review and reform.

The commander's ascendancy in Fiji's political life was driven especially by his determination to expunge the nationalist influence that, since the crisis of 2000, he had viewed as a threat to the integrity of the army under his control. His rhetoric about the army's responsibility to safeguard the nation has been compelled by this preoccupation no less than by a concern for order, justice, and well-being in Fiji's multi-ethnic society. The army has become the pre-eminent institutional vehicle of ethnic Fijian power - paradoxically set against Fijian nationalism, and harshly dismissive of the GCC as being mainly aligned with that force. Army leaders now seek to relegate the chiefs to a 
compliant, supportive role in the project of cleansing the nation of alleged corruption and bad governance.

\section{The Great Council of Chiefs as an instrument of colonial rule}

The GCC was created by the first colonial governor, Sir Arthur Gordon, following his consultations with an assembly of chiefs on how the Fijians should be governed. It became the major symbol of Fijian identity and strength in the colonial political structure and continued to have this significance after independence, ritually affirming an ethnic political unity transcending geographical and cultural differences among Fijians in opposition to the other sections of Fiji's population.

Under British rule, the GCC embodied the privileged relationship of trust and protection established between the Fijians and the British when the leading chiefs voluntarily ceded the islands to the Crown in 1874. The colonial governors chaired meetings of the GCC - held every year or two with rich ceremonial protocol, usually in the villages of pre-eminent chiefs - in order to consult about policy and legislation for Fijian affairs and, until 1963, to select the Fijian representatives for the colonial parliament.

Councils of chiefs had long been important in Fijian political life, and the chiefs who assembled to discuss ceding their islands to the British Crown formed, perhaps, the greatest of such assemblies. Although in pre-colonial times there had been no enduring council of representatives from all chiefdoms, the GCC can be said to have roots in Fijian tradition - as well as in the ideas of British colonial officials. It is the classic 'neo-traditional' institution, established through a blending of traditional forms of rank and political procedure with colonial law and its administrative and consultative requirements. ${ }^{1}$

Throughout most of the colonial period, the GCC continued to be almost exclusively a forum of high-ranking hereditary chiefs, and included many senior officials in the Fijian Administration, the body charged with supervising village life. The most influential members have been paramount chiefs of southeastern Viti Levu and the eastern islands. In the last 20 years of British rule they were Ratu Sir Lala Sukuna, Ratu Kamisese Mara, Ratu George Cakobau, Ratu Edward Cakobau, and Ratu Penaia Ganilau. All began their political careers as GCC nominees to the colonial parliament, and, especially in the context of ethnic tensions, preserved their leadership after Fijians were given the franchise in 1963. The last four of these chiefs dominated the political arena in the transition to independence, and Ganilau and Mara continued to exercise powerful influence until recent times, dying in 1993 and 2004 respectively.

From the 1950s, with rising numbers of Fijians entering the modern economy as wage-earners, membership of the GCC was broadened to allow representation 
of trade unions and other urban organizations. It was becoming, Ratu Mara once explained to critics, more a 'chiefly' council than a council of chiefs, characterized by 'a certain standard of behaviour which can be performed by all sections of Fijians... a standard of behaviour for which all Fijians aim'. ${ }^{2}$ This trend was strengthened after independence, when all Fijians elected to the lower house of parliament were made ex-officio members of the GCC. By the late 1970s, sometimes half the GCC members were commoners or people of modest chiefly rank. ${ }^{3}$ The GCC had become 'an assembly of Fijian leaders from all walks of life, with divergent interests' ${ }^{4}$

Soon after Rabuka's coups, however, the GCC, with the encouragement of the military, reverted to being almost exclusively a council of hereditary chiefs, and so it remains today. The then Minister of Fijian affairs, an army colonel, explained that 'while we appreciate the contributions made by commoners... it is becoming increasingly evident that the chiefs can be outvoted ...[W] hat we want is for the commoners to act as advisers while the decision-making is left entirely to the chiefs'. ${ }^{5}$ Rabuka himself lamented that 'there are so many non-chiefs there who will try to dictate the resolutions ...[T] he chiefs are so humble, their personalities and their character do not make them forceful enough when they discuss matters. They will agree, they will compromise... whereas those who are not chiefs in [the GCC] tend to be very very selfish...' ${ }^{6}$ This view received no vindication from the turmoil stirred up by aggressive chiefly rivalries in the GCC in recent years, especially during the coup crisis of 2000.

Today the GCC has 54 members. Each of the fourteen provincial councils chooses three. There are four ex-officio members - the President and Vice-President of Fiji, and the Prime Minister and the Minister for Fijian Affairs. The latter nominates an additional six chiefs, and the Council of Rotuma has two delegates. The members form a wide spectrum of experience and outlook. A few have tertiary education, careers as bureaucrats, professionals, or politicians, and are widely travelled. But most have relatively little formal education and many live mainly in their home villages. While some have progressive views on the sharing of power and resources, the majority have very ethnocentric outlooks.

While the GCC membership has undergone this regressive change since 1987, its powers have been enhanced. The 1990 constitution increased its delegates to the Senate from 8 (of 22) members - as it was under the 1970 constitution to 24 (of 34) members, and empowered it to decide the appointments of the President and the Vice-President of Fiji. This authority is retained in the current (1997) constitution, although the GCC's strength in the Senate is reduced to 14 (of 32) seats. While commoners and people of modest chiefly rank have been largely excluded from the GCC, they have for many years predominated among the elected Fijian members of the House of Representatives. 


\section{The GCC's dual political role}

The GCC's official entitlements have accorded with a widely held view that, in embodying a concept of indigenous paramountcy, the chiefs are an essential source of legitimacy for a national government. The status afforded the chiefs signifies both the appeasement of a powerful vested interest group and the preservation of an institutional mechanism that has helped to constrain Fijian nationalism. The chiefs' collective authority has been grounded not only in the part they have played in asserting indigenous solidarity in opposition to other groups, especially the Indians, but also, paradoxically, in their capacity to mitigate ethnic conflict. Ethnocentric opinions are often aggressively voiced. Yet in enhancing Fijian convictions of political and cultural strength, the GCC meetings have sometimes been conducive to inter-ethnic accommodation.

Fiji developed under colonial rule as a deeply bifurcated society. The majority of Fijians were compelled to remain predominantly subsistence farmers almost until the end of British rule. In contrast, the Indians entered various sectors of the money-based economy. The importance that the GCC acquired in the national political arena was based on the depth of this ethnic divide and on the need to bridge it. Through the GCC, the colonial governor and Fijian political leaders periodically sought to persuade Fijians - who viewed non-Fijian strengths in the modern economy as reflecting their own economic weakness - to agree to inter-ethnic compromises on both land and the political system.

The GCC could be persuaded to play this bridging role because it securely embodied Fijian identity and strength, and because a readiness to agree to concessions in support of interests in the wider society and of Fiji's economic development came to be seen as part of the chiefs' role in their privileged relationship with the British Crown. There was a perception in the GCC that the British officials' primary concern was indigenous security, and that the chiefs had a reciprocal duty to support the officials in their government of the colony. The most notable early instance of the GCC's bridging role was Ratu Sukuna's success in 1936, on behalf of the colonial governor, in persuading his fellow chiefs to agree to a proposal to give control of the leasing of Fijian land to a central statutory authority in order to overcome problems in personal negotiations between land-owning clans and their sugar cane farmer tenants. ${ }^{7}$ British officials hailed Sukuna's achievement as a breakthrough for economic development and praised the chiefs for their 'statesmanlike attitude towards the general affairs of the colony'. 8

As preparations to end colonial rule raised ethnic tension, the GCC took on a strengthened political role as the major voice of conservative Fijian opinion on constitutional change. The Council continued to enjoy privileged representation in the parliament after Fijians were given the vote for choosing most of their representatives, and it was regularly consulted by the Governor and elected 
Fijian leaders (principally chiefs who had begun their political careers as GCC nominees).

The GCC continued also to be important in facilitating legislative reforms benefiting Indian tenants on Fijian land. In the 1960s the GCC was persuaded by the paramount chiefs, now leaders of the Alliance Party, to agree to the Agricultural Landlord and Tenant Ordinance (ALTO). During a short phase of heightened ethnic tension near the end of colonial rule, which almost erupted in widespread violence, the GCC called for the withdrawal of this concession. Yet, after anti-Indian rhetoric in the Council's meeting, this and other proposals against Indians were not pushed, and several years after independence, Fijian political leaders persuaded the GCC to consent to another land reform primarily of benefit to tenants, the 1976 Agricultural Landlord and Tenant Act (ALTA). Lest an impression be given that Fijian leaders have easily persuaded GCC assent to such proposals, it should be emphasised that argument at Council meetings has often been heated, with suspicion and anger sometimes directed against leaders seen to be compromising Fijian interests.

The independence constitution strengthened the political power of the GCC by giving it reserved seats and a limited veto power in the Senate, a privilege proposed by Indian leaders as a concession to the Fijian claim to political pre-eminence. Soon after independence, the GCC came under the influence of the Fijian Nationalist Party (FNP), which called for a constitutional change to permanently secure Fijian control of government. At their 1982 meeting, following an acrimonious election campaign in which Ratu Mara and other chiefs were denigrated by some Indian leaders, GCC members almost unanimously called for implementation of the FNP demand - despite counter arguments by Prime Minister Ratu Mara, and the Governor General Ratu Penaia Ganilau. The GCC did not pursue this demand until 1987, when the Fijian nationalist mood surged aggressively in the street marches and threats of the Taukei Movement after the defeat of Mara's Alliance Party government by a mainly Indian-based coalition.

\section{The army coups of 1987: Managing militant ethno-nationalism ${ }^{9}$}

Events in the year following Rabuka's overthrow of the new government were marked by a sometimes conflicting interplay of several forces in the political arena, centring on the issue of entrenching indigenous power: The army; the sometimes violent Taukei Movement whose leaders included several people of high chiefly rank; and chiefly authority in the form of the GCC and the paramount chiefs (the former Prime Minister Ratu Mara and the Governor-General Ratu Ganilau) who, with GCC support, had long held leadership of the State. 
Rabuka became manager and mediator of these forces. The GCC and the paramount chiefs were the crucial political resources with which he endeavoured to control the extremists within and outside the army. To secure legitimacy for his coup and restore stability, he sought to bind Taukei objectives to chiefly leadership. Most Fijians acclaimed Rabuka's coup as a legitimate assertion of indigenous power against the perceived threat of Indian domination. Yet, what was most significant about the popular response to the crisis was the way in which the old institutions and symbols of ethnic Fijian leadership helped to both articulate and control it, taking from Rabuka - for the most part with his encouragement - the function of asserting the ethnic claim, and so limiting the independent power of the aggressive nationalists.

Rabuka's first council of ministers, set up in the face of Ganilau's opposition, was headed by Rabuka and Mara, and included many Taukei Movement leaders, some of them formerly Mara's colleagues in the Alliance Party. Rabuka then convened a meeting of the GCC in Suva's Civic Centre, while Taukei Movement supporters massed in an adjacent park. This assembly, and subsequent Fijian provincial council meetings, approved the coup and endorsed the Taukei goal of changing the constitution to entrench indigenous control of government.

After the GCC meeting, Ganilau agreed to lead a new council including Mara and Rabuka, but with fewer Taukei activists. There soon followed meetings of the two paramount chiefs with Timoci Bavadra, the deposed new prime minister. They proposed a caretaker government, to be recruited equally from the Alliance Party and the overthrown Labour-National Federation Party (NFP) coalition, and headed by Ganilau. A Constitution Review Committee's majority report to Ganilau had just endorsed the GCC call for Fijian dominance. But the agreement reached in the Mara/Ganilau/Bavadra talks promised only to take 'full account of Fijian aspirations for the betterment of their interests'. When young men rampaged against Indians and their property, Taukei spokesmen excused the outburst as legitimate anger at the lack of progress towards fulfilling the GCC's resolution.

Rabuka soon yielded to the militants, pushed the two high chiefs aside, and appointed a new governing council, this time dominated by Taukei leaders and army officers. But, as his new cabinet foundered on a combination of personal ambitions and inexperience, pressure on Rabuka to regain the chiefs' cooperation mounted. He dismissed his council and appointed Ganilau as president of the newly declared Republic of Fiji. Ganilau then gave the office of prime minister to Mara, who excluded most Taukei from yet another council and brought back some old Alliance Party colleagues. This interim government endured under Mara's leadership until the election in 1992, which was conducted under a new constitution designed to secure Fijian political dominance. 
In its support of the demand for ethnocentric constitutional change, the GCC might be seen as essentially at one with the Taukei Movement. ${ }^{10}$ But there was more to its part in the crisis than this. The GCC was crucial in constraining a volatile nationalist movement that might well have become more violent and oppressive than it did. What most stood out in the turbulent events was Rabuka's attempt to control and mediate the different political forces: Initially relying on the GCC and the two paramount chiefs for legitimacy and stability, later sidelining them under pressure from the extremists, and eventually turning back to the chiefs when the Taukei pressure threatened to overwhelm him.

The Taukei Movement had potential to grow as an independent force, reconstructing Fijian political leadership, for some of its leaders wanted to marginalize the principal chiefs. But the militants were unable to sustain an aggressive ethnic movement independently of the ideology that affirmed the legitimacy of chiefly leadership. Chiefs and their councils continued to hold the cultural and political high ground throughout the crisis.

The ethnocentric government and constitution that resulted from Rabuka's coups are thus more accurately understood as a constrained expression of a potential for a more oppressive ethno-nationalism than as the unbridled triumph of that potential. In this respect, the GCC might be understood as an institutional 'shock absorber' in Fiji's body politic, its long-established ritualized assertion of indigenous Fijian identity and strength dampening the force of aggressive nationalism. Without the GCC, and without the influence the leading chiefs held over it, militant Taukeism would likely have had a more damaging sway.

The coup crisis from 1987 to 1990 dramatized the dual character of the GCC. The GCC embodies, in powerful but institutionally constrained form, the indigenous Fijian conviction of their entitlement to political paramountcy that since the 1960s has co-existed in tension with the constitutional political order bequeathed by the colonial rulers. While political and social order have been disturbed by volatile ethno-nationalist movements driven by that conviction, the GCC has, as an institution, served the national society by allowing the claim of indigenous paramountcy a form of expression that can constrain such movements and facilitate the restoration of order. This explains the paradox of public talk, since 1987, about the GCC's national importance while it continued to uphold ethno-nationalist political demands.

\section{The GCC and liberal constitutional reform}

In May 1988, Ratu Sir Penaia Ganilau told the GCC, 'There's been a change of wind in Fiji. After the first coup the Queen stressed that my main role [as governor-general] was to speak to the GCC. This confirmed that the leadership, the source of life, the future of Fiji, is in your hands'. ${ }^{11}$ Certainly, the GCC had, in the process of crisis management, attained new power in Fiji's political system 
as an extra-constitutional authority to which key political actors turned for support. The GCC's capacity to act as a stabilizing force, while affirming Fijian political strength, was soon being recognized in public discourse. A discussion began about the positive role the GCC might assume, beyond safeguarding Fijian interests by its veto power in the Senate, and its responsibility to select the President and Vice-President of Fiji. The idea first came to the fore in the debate about constitutional reform in the mid 1990s.

Agreement that the GCC should have a strong place in the national polity was a theme that linked a wide range of proposals and mitigated the conflict of ideological extremes, from the Methodist Church and the Soqosoqo ni Vakavulewa ni Taukei (SVT) party, to the Labour/NFP coalition and numerous exclusively Indian bodies. $^{12}$

It was in the constitutional reform process that Rabuka endeavoured to remake himself as a leader for multi-ethnic Fiji. He turned to the GCC for validation of his compromise with Indian leaders - just as he had depended on the GCC to ratify his coup against those same leaders, to secure his first regime, to constrain the chauvinism inflamed by that crisis, to endorse the 1990 constitution, and to authorize the political party (SVT) through which he ruled from 1992 to $1999 .^{13}$

Foreign diplomatic pressures, the declining Indian population, and economic recession disposed Rabuka and his fellow political leaders to agree to constitutional change. But the most crucial factor enabling the reform was the containment of the ethno-nationalist sentiment they themselves had helped foment. Their ability to control this threat to their compromising depended ultimately on their influence in the GCC. There was, in effect, a strategic division of political labour. Rabuka's ruling SVT party had, in its submission to the Reeves Commission, highlighted ethnic conflict, reproved Indians for their alleged prejudices and insensitivities, and reaffirmed Fijian opposition to their political demands. ${ }^{14}$ The submission strongly echoed the nationalist sentiments that Rabuka had championed after his coups. Yet later, the GCC was persuaded by Rabuka, Ratu Mara and his wife Adi Lala (herself a high chief), and NFP leader Jai Ram Reddy to perform a reconciling role - approving a legislative change that reduced its representation in the Senate and restored equitable representation of the major ethnic groups in the lower house, while retaining the GCC's authority to appoint the President and Vice-President.

Some Indian leaders were fulsome in praise of the chiefs' decision. Senator Irene Jai Narayan, a firebrand of the NFP in its early radical years, declared that 'all the citizens of this country look up to the Bose Levu Vakaturaga [GCC] for guidance and leadership' ${ }^{15}$ In the lower house, Harnam Singh Golian, another former NFP militant, expressed 'gratitude' to the GCC 'who have been a source of vision, inspiration, and a pillar of strength in the [constitution] review process, and to whom the whole nation looks...as a symbol of national unity and 
togetherness' ${ }^{16}$ These accolades matched Rabuka's reverence for the GCC as 'not only the highest institution for the protection of Fijian interests, but also the ultimate guardian of the good and orderly government of Fiji, and the... welfare of all its citizens' ${ }^{17}$

\section{The coup crisis of $\mathbf{2 0 0 0}$}

The optimism inspired by the reform was soon brutally shattered. Eight of the 14 Fijian provincial councils opposed the GCC's decision, and the disquiet was widened and intensified by a radical change of government in 1999. The first election under the new constitution was won by a coalition of parties, including several Fijian bodies, but led by the still mainly Indian Labour Party. Labour leader Mahendra Chaudhry was appointed prime minister by President Ratu Mara, whose daughter would be a member of the new cabinet. Soon after taking office, Chaudhry addressed the GCC, reaffirming the assurance given to the chiefs two years before by another Indian leader, Rabuka's political ally Jai Ram Reddy, 'that all communities...look to this great venerable institution for leadership and guidance in the good governance and well-being of our nation' ${ }^{18}$

Fiji's first Indian prime minister wanted to impress on the GCC his respect for Fijian concerns and anxieties. It seemed a promising start for the new government. However, within a few months there grew a groundswell of Fijian anger over some of Chaudhry's plans, especially a proposal to reform the management of their lands - allegedly without proper consultation with the GCC. The hostility culminated in protest marches and a coup d'état led by a civilian, George Speight, with the support of a small section of the army (originally established by Rabuka as his personal force).

The GCC was divided in its response to the crisis. Its capacity as a cohesive force for political stability and compromise has always depended on its openness to persuasion by Fijian leaders, particularly the paramount chiefs. With their encouragement, GCC unity was maintained in the crisis precipitated by Rabuka's first coup and at subsequent critical moments throughout the 1990s: The making of the 1990 constitution, the constitutional reform in 1997, and the GCC's reception of Chaudhry in 1999. But now the chiefs were split between supporters and opponents of George Speight and his fellow coup-makers. Prolonged argument and rivalries have always been features of GCC meetings, but this impasse was unprecedented.

The GCC's failure to unite against the overthrow of a government elected under the constitution it had approved, was due partly to a long simmering resentment of several Bauan chiefs against the continued political pre-eminence of Tovata high chief Ratu Mara. Mara's ability to guide the GCC, as he had usually been able to do in the past, was weakened by ill health, by the fact that his daughter was among the hostages held during the Speight coup, and eventually by his 
resignation as President under pressure from Bainimarama and his advisers. The crisis marked the demise of this frail last survivor of the 'Big Four' paramount chiefs who had led the Fijians to independence from British rule.

The GCC had appointed Rabuka as its chairman following the defeat of his government in the 1999 election. But this erstwhile champion of liberal constitutional reform was now unwilling to push for a firm stand against the coup at the chiefs' meetings. The explanation might partly be that, as the first commoner to hold the office, Rabuka perhaps wished to avoid a possibly humiliating clash at this most volatile moment with his deputy, Adi Litia Cakobau, a feisty Bauan chief who strongly supported the coup.

While, in the crisis of 2000, the GCC failed a crucial test of its now expected national role, the upheaval was the crucible for a strengthening of the army as an independent political force. Commander Bainimarama grappled with the crisis on two fronts: The prolonged hostage situation, and the challenge of controlling his army in the face of ethno-nationalist and vanua (tribal) sentiments that were inflamed by the coup and eventually erupted in a very violent attempted mutiny. Whereas Rabuka's task in 1987 had been simply to control the Fijian nationalists, whose objectives he and his united army supported, Bainimarama faced the far more difficult problems of combating the renewal of that nationalism and crushing Speight's coup. ${ }^{19}$

The GCC redeemed itself as a forum supporting democratic government when, after much debate, it accepted court rulings that the constitution remained in place, appointed a new President, and urged him to order fresh elections for the House of Representatives - a proposal that Chaudhry himself endorsed. In 2001, the Fijian-dominated, Laisenia Qarase-led interim government that Bainimarama had installed, was confirmed in power by election, but only through an alliance with a party led by coup supporters. As well as cultivating nationalist allies, Qarase sought to consolidate the support of the GCC, promising to 'elevate and strengthen' it, and even proposing that 'the sovereignty of this country' be shared between parliament and the GCC. ${ }^{20}$ An independent source of income was established for the GCC, and construction commenced on grand buildings next door to Government House for its meetings and administration, to replace the old venues of chiefly villages, army barracks, and city convention centres.

The image of the GCC as a forum of national importance was enhanced by ritual presentations and submissions to it by two Indian organizations, the Girmit Council (representing major religious, cultural, and educational bodies) and the Fiji Sugar Cane Growers' Council, whose executive asked the chiefs to resolve land problems afflicting the tenant farmers. ${ }^{21}$ However, the GCC later supported Prime Minister Qarase's plan for legislation aimed at 'reconciliation, tolerance, and unity' that would give amnesty to many coup supporters, several of whom he had appointed to his cabinet. ${ }^{22}$ The GCC was aligning with a government 
now strongly influenced by the nationalist leaders on whom Qarase partly relied for his first electoral victory, and whom he would need again for his win in 2006.

As Qarase endeavoured to boost the status of the GCC, confident of its continued support, a conflict grew with the army commander. The crisis of 2000, and the conduct of the government that Bainimarama had installed at its height, provoked a determination in the commander and some of his senior officers to strengthen the military as a corporate community of soldiers within the framework of an ideology that proclaimed their responsibility to work for the good government and stability of the nation, in opposition to Fijian extremists. Under this new creed the commander claimed for the army an on-going independent overseer authority in Fiji's political system. ${ }^{23}$

\section{The 2006 coup}

Toward the end of 2006, Qarase sought help from the GCC, hoping that the chiefs could mediate a resolution of his worsening conflict with Bainimarama. He reaffirmed his belief in the GCC's national role, emphasizing the part it had played in the management of past crises. Both Qarase and Bainimarama were invited to an 'emergency' GCC meeting. Bainimarama declined to attend, declaring that he did not wish the chiefs to become involved in the conflict and condemning Qarase for seeking to use them to resolve his predicament. Qarase explained again to the chiefs the planned legislation that Bainimarama was opposing, and announced that he would seek a Supreme Court ruling on the commander's claim that Fiji's constitution gave the army an independent responsibility to safeguard the security and well-being of the nation. ${ }^{24}$

Bainimarama refused to meet with a GCC mediation committee which tried to visit him at the barracks, and, on 5 December, he ousted Qarase's government, scarcely seven months after its re-election. He persuaded the acquiescence of the ageing and ailing President Josefa Iloilo, ordered Vice-President Ratu Joni Madraiwiwi from his office, and proclaimed that, as army commander, he had assumed executive authority. As the takeover began, the GCC chairman appealed to Bainimarama over national radio, saying, 'Where you are taking Fiji now will only end in grief and hopelessness for all its peoples...You told the GCC you will protect this country. Now you have turned your back on God, the chiefs, our country and the church...' ${ }^{25}$ At its meeting two weeks later, the GCC continued to recognize President Iloilo and the Vice-President and the government of Qarase. The chiefs called on the army to return to barracks and recommended that the President should appoint a council to set up an interim government 'of national unity', on the grounds that the elected government, although still possessing legitimacy, was now ineffective. Bainimarama, who had declined to attend the meeting because the chiefs refused to invite him as the acting President (rather than as army commander) now directed that the GCC 
must not meet again during the 'state of emergency' without army approval. He bluntly made clear that he no longer respected the Council, viewing it as an obstacle to his 'clean-up' work for the well being of the nation. There was briefly a suggestion in the GCC that chiefs should direct their traditional subjects to leave the army. Only one chief attempted, unsuccessfully, to do this, prompting a newspaper editor to remark that for many Fijians the armed forces were 'the new vanua' (Fijian community). ${ }^{26}$

Early in January 2007 Bainimarama declared he was returning executive authority to the President. After the President then appointed him acting prime minister, Bainimarama, retaining his command of the army, selected an interim cabinet of 16 (4 Indians, 10 Fijians, a Rotuman, and a part-European). The GCC chairman initially accepted these appointments. But, at its next meeting, the GCC refused to endorse the President's nominee for Vice-President on the grounds that, as a member of the interim government, this man was complicit in illegal actions. ${ }^{27}$ An angry Bainimarama rebuked the chiefs for their concern about the legality of the coup and the new regime, and for obstructing his 'clean-up' campaign. He directed his Minister for Fijian Affairs, himself a high-ranking chief and the previous army commander and previous GCC chairman, to 'suspend' the GCC and initiate a review of its composition and role in preparation for a reform. Bainimarama explained his action in an address on national radio. It was clear, he said, that the GCC 'does not recognise the interim government', and therefore it 'now constitutes a security threat in our efforts to move the country forward' ${ }^{28}$ A 'task force' of several prominent chiefs was appointed to conduct the review.

In response to this unprecedented affront to the GCC, several of its leading members declared that they would take the matter to court, their resolve boosted by the European Union's threat to withhold aid funds if the GCC's autonomy was not respected. ${ }^{29}$ Perhaps the most telling moment in the commander's assertion of his dominance over the chiefs was the military escort of a high-ranking chief from his home to the barracks for interrogation where he was cautioned about his statement at the GCC meeting against the interim regime. ${ }^{30}$

In the crisis of 1987 the military was the catalyst for the GCC's assumption of a national political role, and in the 1990s, the coup-maker, as prime minister, continued to rely on GCC support. Rabuka had perpetrated his coups with the aim of strengthening indigenous Fijian power, and there was no voiced disapproval of this objective within the GCC. The army and the GCC had been supported by the leading chiefs during most of the first coup crisis and, except for three months, following the second coup. The Fijian nationalist hostility provoked by the electoral defeat of Mara's government had united these three established forces of indigenous power: The army, the GCC, and the paramount chiefs. 
Bainimarama's declared objective both in 2000 and 2006 was to combat Fijian nationalism, which he viewed as a threat not only to the security and well-being of Fiji as a nation, but particularly to the integrity of his army and to his command. In 2000, he faced a GCC disabled by division in response to Speight's coup. But in 2006-07 he confronted a GCC predominantly opposed to his overthrow of the government that 80 per cent of Fijian voters had only recently returned to power. This impasse has made it difficult for Bainimarama to achieve legitimacy for his takeover, at least in the eyes of most indigenous Fijians. It seems likely that he will have to continue to rely more than did Rabuka on the resources of the army, both physical and ideological, to maintain his control. However, he has been supported in his conflict with the GCC by two former army commanders, both high chiefs closely related to the Mara family, and both members of the interim regime (one his military mentor, the other the man he favours for Vice-President), and by a son of Mara who holds senior military rank. Certain Bauan chiefs, who had once swayed many in the GCC to endorse Speight's coup, have been conspicuous for their reluctance to voice opposition to the regime.

\section{Conclusion}

Fiji's political development since late colonial times has been primarily a story of the assertion and containment of the indigenous Fijian claim to power. Efforts to develop strongly multi-ethnic parties have been unsuccessful, obstructed mainly by the force of indigenous nationalism which began, soon after independence, to weaken the ability of the leading high chiefs to expand Indian support for their Alliance Party, and which has sometimes had powerful influence in the GCC. The Labour Party in 1987 was mainly supported by Indians, and its coalition partner, the NFP, was almost entirely so. In 1999, the still largely Indian Labour Party depended on a fragile coalition of convenience with Fijian parties (two of them nationalist) that was fracturing before Speight's coup. The possibility of government committed to the welfare of the multi-ethnic society, to the limited extent that such government has been achieved, has depended on the preservation of Fijian control.

It does seem that ethnic Fijian power, in some institutional form, is the necessary keystone in Fiji's political architecture. The Fijian claim to power has been asserted through several different forms of leadership and institution: The GCC, with its privileged representation and veto power in the Senate; the paramount chiefs who, from 1966 to 1987, assured the Fijian people that through the Alliance Party they would retain political power; aggressive ethno-nationalist parties and movements demanding a 'Fiji for the Fijians'; and the army - the gold standard for ensuring Fijian power, with its own capacities to both assert and restrain ethno-nationalism. Political events have been marked by the fluctuating strengths and interplay of these forces. The ascendancy of the army in the 
political arena is to be understood partly in terms of the institution's own strengthening since independence by UN peace-keeping work, but more importantly in relation to the eventual failure of chiefly leadership as an arm of Fijian power, and indeed the failure of other projects of Fijian political leadership, to build a multi-ethnic base for national government.

While the GCC has sometimes been swayed by militant ethno-nationalism, it has also helped to dampen or contain it by its institutional capacity to reconcile the ritual assertion of ethnic Fijian identity and strength, with debate and compromise facilitating inter-ethnic accommodation. The GCC has acted in this way with the encouragement of political leaders, especially the paramount chiefs. Similarly, although the army has been influenced by aggressive nationalism - and nationalist convictions have sometimes permeated its ranks - these forces have also been subdued by leadership, as under Bainimarama's command.

For all its current declarations of a commitment to ensure 'good governance' for Fiji, the most significant fact about the military is that it is the most powerful institutional embodiment of indigenous Fijian identity and strength. Yet the army both embodies Fijian power and possesses the resources of organization, skilled personnel, coercive authority, and professional ethos to support government for the multi-ethnic society. A continuing political role for the army might possibly be a viable way of reconciling the Fijian conviction of their entitlement to power with the interests of other sections of the society. Perhaps by the army assuming some form of guardian role in relation to government, ethnic Fijian power could be seen as being secured outside the electoral arena, thereby freeing political rivalry for stronger inter-ethnic cooperation than before. In any case, the army officers, having acquired experience and new status in dominating national political life, are likely to claim an on-going monitoring authority even after a restoration of democratic elections. A major concern, of course, is whether the military can be persuaded to curb its disposition to suppress some of its strongest critics by the use or threat of physical force.

In the interplay of political forces centring on the assertion and management of the indigenous claim to power, Fiji's military leaders have changed from their initial deference to the GCC, to an assertion of power over it. Bainimarama is not the first military strongman to try to control the GCC. Rabuka sought to manipulate the forum by barring certain chiefs and leading commoners opposed to him from attending its meetings, and it was under his rule that the membership was reverted in the early 1990s almost exclusively to chiefs after thirty years of broadening representation. Rabuka was sometimes accused by his political adversaries of using the GCC as a 'rubber stamp' for his policies. ${ }^{31}$

There has been much discussion over the last decade about the need to reform the GCC by again broadening its membership to include more well-educated members to better equip it to respond usefully to Fiji's contemporary problems 
and to strengthen its capacity to resist ethnic extremism, and by making it accessible for consultations with various interest groups, leaders, and advisers, while protecting its autonomy from political parties and government. ${ }^{32}$ Bainimarama and Ratu Epeli Ganilau, his Minister for Fijian Affairs, are proposing reforms that might achieve some of these objectives, but would end the GCC's status as a forum with claim to political autonomy. Their plan is to subordinate the chiefs to government: 'The GCC is an arm of government and it exists to support government'. 33 Ironically, Ganilau, as the previous chairman of the GCC, had opposed some major policies and decisions of the Qarase government, provoking Qarase to arrange his replacement before his term expired.

Bainimarama's contemptuous treatment of the GCC highlights dramatically the question of the Council's future significance as a political agent in a rapidly changing Fiji. The GCC attained its prominence in the political arena in the context of the deep bifurcation of colonial Fiji, the divide between a compartmentalized subsistence, village-based indigenous population, and a strengthening market-based economy driven mainly by European capital and Indian labour and enterprise. British rulers encouraged the GCC to facilitate both the segregated paternalistic government of the Fijians and the political bridging of the divide, especially to support the lease access of Indian farmers to Fijian clan lands, but also to establish a strong political identity for Fijians in the context of the conflicts and tensions of this divide, a powerful symbolic and political presence in the colonial society that paradoxically enhanced the GCC's capacity to play an accommodating role across the divide.

Two related trends might weaken the significance that the GCC had achieved in Fiji's political system: The increasing Fijian majority in Fiji's population, and intensifying Fijian political rivalries. Urbanization has reduced the rural village people from a large majority of the Fijian population at the time of independence in 1970, to barely half the Fijian population today. Ironically, this change accelerated as the GCC reverted to being a forum that largely excluded representatives of urban interests. While Fijians increasingly view the GCC as losing much of its relevance, a relic of the colonial era, the institution has retained importance as a bastion of indigenous strength in the context of ethnic political tensions. However, the political weight of the ethnic divide has been diminished by demographic change, with the Indian population falling from nearly 49 per cent in 1986 (Fijians 46 per cent) to the present 38 per cent (Fijians 53 per cent), and by the dominance of Fijians in most domains of government and in government-linked corporations. At the same time, there has been a strengthening of Fijian rivalries for political power or advantage. These rivalries are tending to outweigh the old ethnic conflict, and have at times threatened to overwhelm the GCC's capacity to achieve consensus on matters of crucial national importance, a capacity that had become central to the Council's significance in the past. 


\section{Postscript}

New regulations for the GCC were gazetted in February 2008, while several leading chiefs in the old GCC awaited the outcome of their legal challenge to its dissolution. ${ }^{34}$ The changes strike at the autonomy of the GCC and will exclude many former members, including several high ranking chiefs. While Fiji's President, Vice-President and prime minister will no longer be ex-officio members, the Minister for Indigenous Affairs remains with the status of chairman and with much greater power than before. The rules aim to realize the army commander's view that the GCC should primarily be an instrument of government, insulated from electoral and parliamentary politics, especially the influence of Fijian nationalist groups. The attempted political taming of the GCC echoes Bainimarama's earlier preoccupation with ridding his army of this influence. Whoever wins government will have considerable power over the make-up and conduct of the GCC.

Forty-two of the 52 members are to be representatives of the chiefs of the 14 provinces (three from each). Each chief 'shall have demonstrated exemplary leadership in Vanua and in the community at large, and shall be appointed by the minister', who presumably will make the final judgement on the achievement of these qualities. The minister will also appoint an additional six chiefs as 'co-opted members', and three representatives of the chiefs of Rotuma. All appointments are to be for three years with the possibility of renewal.

Most controversial is the requirement that all members must be formally installed chiefs. It is estimated that at least 60 per cent of chiefly titles are vacant, in many cases because of disputes over rightful succession. In the past this has not restricted the provincial councils when selecting their representatives to the GCC; indeed, in certain provinces, formal installation has not been the customary practice. The new regulations do not specify the method by which chiefs representing a province are to be selected, only that they will be appointed by the minister. However, provincial councils are being told that leading chiefs of each province must meet to nominate chiefs for appointment: The Bose ni Vanua (Council of Chiefs) of a province is to be the "nominating authority under the minister's mandate'. ${ }^{35}$ Formerly, the provincial councils elected their representatives and these were not required to be chiefs. ${ }^{36}$ The minister previously decided only the appointments of the additional six Fijian members (who had to be chiefs). In future, apparently, the minister is to have the final say in the selection of the provincial members.

There are further new restrictions on membership. Chiefs will be ineligible if, during the previous seven years, they have been members of the House of Representatives or election candidates for such seats, or have been non-GCC nominated members of the Senate. Also excluded are those who have been political party office-holders in this period, those who hold 'public office', and 
any who have served prison terms of more than six months during the previous 10 years. The new regulations ignore a long-standing central issue in debates about reforming the GCC: The desirability of having among the members more individuals with advanced formal education and specialist expertise. A concern to enhance the independent capacity of the GCC to make well-informed decisions is apparently not high on the interim regime's reform agenda.

Under the old regulations, the Minister for Fijian Affairs could neither fully control the agenda of the GCC nor exercise punitive sanctions against members. In the 'new look' GCC the members are to be restricted to discussion and recommendations on issues, policies, and draft laws relating to Fijian and Rotuman people 'which the minister may refer to the GCC'. The minister will also have authority 'to suspend, dismiss, or take disciplinary action against a member...for bringing the GCC into disrepute or for any other good cause'.

The GCC Task Force team has visited provincial councils to explain the changes and to persuade them to convene meetings of their chiefs for the purpose of proposing members for a new GCC. The team leader has stressed the urgency of convening the GCC in order to fill the vacant office of Fiji's Vice-President in preparation for the death or retirement of the President. Failure to do this, he warned, would lead to a 'constitutional crisis'. ${ }^{37}$ In an attempt to win them over, the provincial councils are being told that for the first meeting of a new GCC their chiefs are allowed to directly 'appoint' their representatives, who will be able to propose amendments to the new regulations ('they are not set in stone' $^{\prime 38}$

The responses from the provincial councils have highlighted a continued Fijian opposition to the regime, at least from most provincial leaders. At the time of writing, only four councils (Macuata, Bua, Serua, and Lau) had supported the reforms. ${ }^{39}$ Eight councils have rejected the changes on the grounds that the regime is illegal and had acted disrespectfully toward the chiefs - in the words of one chief, the reform of the GCC has been 'forced on people through the power of the gun' ${ }^{40}$ In some of the provincial councils most strongly opposed to the reform, the chairmen are either now disqualified from GCC membership or are appellants in the current legal action against the regime for dissolving the old GCC. Two councils refuse to make their decision until the court has made its ruling. Among the councils opposing the new regulations are Rewa, Tailevu, and Cakaudrove, the provinces of Fiji's pre-eminent high chiefs.

Bainimarama has warned that if necessary he, as the new Minister for Indigenous Affairs, will appoint provincial representatives for the GCC regardless of the widespread opposition; he claims that a number of chiefs have volunteered their personal support. ${ }^{41}$ But he suggests that if a new GCC meeting fails to achieve a quorum (35 of the 52 members), a referendum among the citizens might be held to choose a President and Vice-President. 


\section{ENDNOTES}

1 Nayacakalou, R. 1975. Leadership in Fiji, Melbourne: Oxford University Press; Macnaught, T. 1982. The Fijian Colonial Experience: A study of the neo-traditional order under British colonial rule prior to World War II, Pacific Research Monograph \#7, Australian National University, Canberra; Norton, R. 1999. 'Chiefs for the Nation: Containing Ethno-nationalism and Bridging the Ethnic Divide', Pacific Studies 22(1):21-50; Newbury, C. 2006. 'Bose Vakaturaga: Fiji's Great Council of Chiefs', Pacific Studies 29(1\&2): pp.82-127.

2 'Chiefly council' is the literal translation of the Fijian title of the GCC: Bose Levu Vakaturaga (Fiji Legislative Council Debates, May 1966: 92). Sir Arthur Gordon's account of the earliest councils is in Gordon, A. 1883. 'Native Councils in Fiji', Contemporary Review 43:711-731.

${ }^{3}$ Lasaqa, I. 1984. The Fijian People: Before and After Independence, Canberra: Australian National University Press, pp.161-164.

4 Ibid p. 162

5 The Fiji Times 16 February 1988.

6 Dean, E. and Ritova, S. 1988. Rabuka: No Other Way, Doubleday, Sydney.

7 Norton 'Chiefs for the Nation', pp. 33-35; Scarr, D. 1980 Ratu Sukuna: Soldier, Statesman, Man of Two Worlds London: Macmillan Education Limited.

8 Norton 'Chiefs for the Nation', p. 34

9 This section is based on Norton, R. 1990, Race and Politics in Fiji 2nd revised edition, St Lucia:

University of Queensland Press, Chapter 7. For detailed accounts of the 1987 coups and their aftermath, see Lawson, S. 1991, The Failure of Democratic Politics in Fiji Oxford: Oxford University Press; Howard, M. 1991. Fiji: Race and Politics in an Island State, Vancouver: University of British Columbia Press, and Lal, B. 1992, Broken Waves: A History of Fiji in the 20th Century, Honolulu: University of Hawaii Press.

10 Lal, Broken Waves, p. 289.

11 Nai Lalakai (Fijian newspaper), 5 May 1988.

12 Norton, R. 2000 'Reconciling Ethnicity and Nation: Contending Discourses in Fiji's Constitutional Reform', The Contemporary Pacific 12(1)83-122, p. 110.

13 Lal, B. 1998, Another Way: The Politics of Constitutional Reform in Post-Coup Fiji, Canberra: Asia-Pacific Press; Norton, 2000, Reconciling Ethnicity and the Nation.

14 Norton, R. 'Reconciling Ethnicity and the Nation', pp. 97-99.

15 Irene Jai Narayan, Fiji Parliament, Senate, Daily Hansard, 20 August 1997 p.869.

16 Harnam Singh, Fiji Parliament, House of Representatives, Daily Hansard, 24 June 1997 p.318.

17 Sitiveni Rabuka, Fiji Parliament, House of Representatives, Daily Hansard, 23 June 1997 p.311.

18 The Fiji Times, 14 June 1999.

19 Bainimarama, overseas when the coup occurred, returned to an army in danger of splitting. He maintained his control with the backing of his land force commander, Viliame Seruvakula, who had refused attempts by coup supporters to win him over. In his subsequent efforts to rid the army of nationalist leanings, Bainimarama continued a project begun many years earlier by his predecessor and mentor, Ratu Epeli Ganilau, whom he had succeeded scarcely a year before to the consternation of rival officers. For detailed accounts of the 2000 coup and its aftermath, see Robertson, R. and Sutherland, W. 2001, Government By the Gun: The Unfinished Business of Fiji's 2000 Coup, Sydney: Pluto Press; Fraenkel, J. 2000 'The Clash of Dynasties and the Rise of Demagogues : Fiji's Tauri Vakaukauwa of May 2000', Journal of Pacific History 35(3): 295-308.

20 Fiji Parliament, House of Representatives, November 2001, Appropriation debate. Quoted on Fiji Government website Fiji Government Online, 28 November 2001.

21 The Fiji Times 15, 17, 18, 23 November 2003. The presentations were made at a time when the GCC chairman, Ratu Epeli Ganilau (a critic of the Qarase government), was encouraging dialogue with Indian leaders.

22 The Fiji Times, 29 July 2005. On the Promotion of Reconciliation, Tolerance and Unity Bill proposal, see Bhim, M. 2007, 'The impact of the Promotion of Reconciliation, Tolerance and Unity Bill on the 2006 election', in J. Fraenkel and S.Firth (eds) From Election to Coup in Fiji: The 2006 campaign and its aftermath, Canberra: Asia Pacific Press, and Suva: Institute of Pacific Studies, pp. 111-143.

23 The new ethos that Bainimarama and his most senior officers have been endeavouring to build in the RFMF is reflected in documents on the army's web pages; see especially Mataivalu News and 'Commander's Intent 2008'. 
24 Bainimarama invokes a clause in Fiji's current constitution which, he insists, implicitly preserves the following provision in the previous constitution promulgated in 1990, 'It shall be the overall responsibility of the Republic of Fiji Military Forces to ensure at all times the security, defence and well-being of Fiji and its peoples' (Constitution of Fiji, 1990, Clause 94 (3). P.86). For detailed accounts of the coup and its aftermath see Chs 1-3, this volume.

25 The Tui Tavua, Ratu Ovini Bokini, The Fiji Times, 5 December 2006.

26 Fiji Sun, 16 December 2006.

27 Chiefs of two of the three traditional political confederacies (Kubuna and Burebasaga) rejected the nomination, while the third (Tovata) supported it. Under the 1997 constitution, the President's nominee is appointed Vice-President if approved by the GCC, but there is no specification of the procedure to be followed in the event of the GCC rejecting the President's nomination. It should be noted that Bainimarama is himself of chiefly status (in Tailevu Province), and that in his treatment of the GCC he has been supported by two very high ranking chiefs in his regime (both former army commanders and one a former GCC chairman).

28 Fiji Government Online, 13 April 2007: 'There are strong indications' Bainimarama said, 'that the Council has now become a forum for furthering certain political agendas which can be detrimental to the interim government's efforts to move the country forward'.

29 The Fiji Times, 26 April 2007.

30 Ratu Timoci Vesikula of Verata, a prominent minister in Rabuka's government, The Fiji Times, 14 April 2007.

31 Rabuka's 'manipulation' of the GCC mainly took the form of informally exercised pressure. The Fijian Association Party (FAP) leader, Josefa Kamikamica, complained in 1995 that Rabuka and his fellow leaders in the GCC-endorsed SVT Party were excluding from GCC meetings, chiefs who supported the FAP (The Fiji Times, 31 July 1995). Rabuka's political opponents accused him of trying to 'stack' the GCC with his supporters, and of using the GCC as a 'rubber stamp' for his policies and decisions, including his work for constitutional reform. Rabuka, some critics alleged, was 'belittling the integrity of the chiefly forum' (FAP leader V. Saulekaleka, The Fiji Times, 8 May 1997). See also the debate of a FAP proposal to broaden GCC membership, House of Representatives, Daily Hansard, 8-9 December 1994, pp.2558-2583).

32 See especially Reeves, Sir P., Vakatora, T., Lal, B. 1996 The Fiji Islands: Towards a United Future. Report of the Fiji Constitution Review Commission, Parliament of Fiji, Parliamentary Paper No.34 of 1996, 256-262; and Ministry of Fijian Affairs, 2002 'Review of the Fijian Administration' (in 2 vols) Parliamentary Papers 70 and 71 of 2002. Vol1: 20-21, 34-39.

33 The Fiji Times, 8 August 2007.

34 Republic of Fiji Islands Government Gazette (Extraordinary) Vol 8 No.12, 13 February 2008 - Fijian Affairs Act, Fijian Affairs (Great Council of Chiefs) Regulations 2008.

35 The Fiji Times, 28 April 2008.

36 Fiji Republic Gazette Supplement No.18, 7 May 1993, Legal Notice No. 29, Fijian Affairs (Great Council of Chiefs) Regulations 1993.

37 The Fiji Times, 29 April 2008.

38 The Fiji Times, 2 May 2008.

39 The Fiji Times, 21 May and 28 June 2008; Fiji Daily Post, 26 May 2008; Fiji Sun, 29 June 2008.

40 Ro Filipe Tuisawau of Rewa Province, The Fiji Times, 19 April 2008.

41 The Fiji Times, 13 May 2008. 